\title{
Evaluasi Uji Banding Antar Laboratorium untuk Mengukur Kompetensi Personil
}

\author{
Harjito $^{1}$ \\ 'Laboratorium Hidrologi dan Klimatologi Lingkungan, F.Geo, UGM,Yogyakarta, 55281, \\ Email: harjito@ugm.ac..id
}

Submisi : 12 Agustus 2019; Penerimaan: 30 Agustus 2019

\begin{abstract}
Telah dilakukan kegiatan uji banding antar laboratorium dengan parameter kimia terbatas yaitu Besi ( $\mathrm{Fe}$ ). Penelitian ini bertujuan menentukan dan memonitor kesinambungan unjuk kerja laboratorium dalam pengujian tertentu dan mengetahui kompetensi personil dari laboratorium penguji peserta. Cara pengolahan data uji banding dalam menguji Besi menggunakan z-score. Sampel air yang diujikan sebanyak $500 \mathrm{~mL}$ yang dikemas dalam botol plastik tertutup rapat. Pengujian parameter Besi secara spektrofotometrik dilakukan serentak di 14 (empat belas) laboratorium penguji, Hasil perhitungan nilai z-score data hasil pengukuran konsentrasi Besi menunjukkan bahwa terdapat dua laboratorium penguji yang berada dalam kategori kurang memuaskan, yaitu laboratorium dengan kode LUB-1 dengan nilai Z-Score 4.14 dan LUB-5 nilai Z-score -3.32; dua laboratorium diragukan kode LUB 4 dengan nilai Z-Score 2.17 dan LUB-15 dengan nilai Z-score; sedangkan 10 (sepuluh) laboratorium penguji lainnya termasuk dalam kategori kompeten termasuk Laboratorium Hidrologi dan Klimatologi Lingkungan Fakultas Geografi UGM,sehingga kemampuan personil dalam melakukan pengujian tidak diragukan.
\end{abstract}

Kata kunci: uji banding; kompetensi; laboratorium; personil.

\section{PENDAHULUAN}

Dalam kehidupan modern saat ini
kualitas hidup masyarakat dunia
mendapat perhatian yang serius dalam
berbagai aspek kehidupan. Kualitas
produk, jasa maupun komoditas yang
digunakan oleh masyarakat sehari-hari
menjadi isu penting yang sangat
diperhatikan standarnya. Rendahnya
kualitas suatu produk, jasa maupun
komoditas dapat berdampak terhadap
menurunnya pendapatan ekonomi,
kesehatan manusia bahkan merusak
lingkungan yang akhirnya menurunkan
kualitas hidup manusia. Sesuai dengan
amanah Undang-Undang Republik
Indonesia No.32 Tahun 2009 mengenai

perlindungan dan pengelolaan lingkungan hidup agar dapat berjalan efektif dan efisien bila didukung oleh hasil uji yang akurat dan dapat dipertanggungjawabkan secara hukum dan ilmiah.Untuk menjamin data hasil pengujian supaya mendapatkan pengakuan yang berlaku internasional, diperlukan 3 elemen kunci yaitu sistem akreditasi, pelaksanaan prosedur kontrol kualitas internal serta keikutsertaan dalam uji profisiensi antar laboratorium (Styarini,D,2010).

Menurut dokumen standar SNI-1917025-2017 tentang persyaratan kompetensi laboratorium kalibrasi dan penguji, kompetensi laboratorium dapat 
dinilai secara teknis diantaranya melalui ketersediaan personel teknis dengan kemampuan yang memadai dan sesuai dengan rung lingkup pengujian, peralatan yang sesuai dan terkalibrasi serta jelas ketertelusurannya ke satuan $\mathrm{SI}$, metode pengujian yang sesuai, dan adanya mekanisme yang dijalankan untuk menjamin mutu hasil pengujiani. Salah satu upaya yang dapat dilakukan untuk menjamin mutu hasil pengujian adalah dengan berpartisipasi dalam uji banding antar laboratorium. Bahkan, sebuah laboratorium yang terakreditasi mempunyai kewajiban untuk berpartisipasi dalam uji banding yang diselenggarakan oleh badan akreditasi terkait di negara tersebut sebagai salah satu upaya badan akreditasi tersebut untuk memantau kemampuan teknis laboratorium terakreditasi secara berkala (Zaid dkk,,2011).

Pada dasarnya setiap hasil pengujian dari suatu laboratorium bisa dipastikan tidak akan terlepas dari adanya kesalahan atau galat. Timbulnya kesalahan bukan merupakan disengaja namun bisa dimungkinkan kesalahan yang tak dapat dihindari baik pada prosedur pengujian di fisika maupun kimia. Berbicara mengenai pengujian kimia biasanya akan jauh lebih rumit dibandingkan dengan pengujian fisika. Umumnya akurasi yang diperoleh pada pengujian kimia untuk level konsentrasi yang sangat kecil akan rendah, Hasil pengujian pada contoh uji yang sama oleh dua atau lebih laboratorium bisa dipastikan akan menghasilkan nilai yang berbeda, karena tergantung dari kemampuan masing-masing personil yang melakukan pengujian. Evaluasi menggunakan statistik merupakan tolok ukur sejauh mana perbedaan hasil tersebut dapat diperbandingkan atau dianggap sama atau tidak sama terhadap kemampuan personil laboratorium. Dengan mengikuti kegiatan uji profisiensi akan terlihat apakah hasil uji suatu laboratorium akurat, memuaskan atau dapat diterima. Adapun tujuan utama dilakukannya uji banding antar laboratorium adalah untuk menyediakan perangkat jaminan mutu bagi laboratorium-laboratorium dalam membandingkan kinerja suatu laboratorium terhadap laboratorium lain yang sejenis, sehingga dapat mengambil langkah perbaikan yang diperlukan bila ada ketidaksesuaian.

Uji banding atau Interlaboratory comparison (ILC) adalah organisasi, kinerja serta evaluasi dari suatu hasil pengujian/kalibrasi dari suatu matriks atau contoh uji yang sama oleh dua laboratorium atau lebih dimana kondisi pengujian telah ditentukan sebelumnya. Suatu laboratorium harus memiliki prosedur quality control untuk memonitor validitas dari hasil uji dan kalibrasi yang dilakukan. Monitoring dapat meliputi keikutsertaan pada uji banding antar laboratorium atau program uji profisiensi dan juga dapat melalui penggunaan bahan acuan yang tersertifikasi atau dengan melakukan replikasi pengukuran menggunakan metoda analisa yang sama atau berbeda. Dengan demikian laboratorium dapat menyediakan bukti kompetensinya pada pelanggannya dan kepada lembaga akreditasi. Makalah ini mendiskusikan salah satu hasil uji banding yang telah diikuti Laboratorium Hidrologi dan Klimatologi Lingkungan Fakultas Geografi UGM sebagai laboratorium penguji yang sudah terakreditasi oleh Komite Akreditasi Nasional (KAN) dengan Nomor sertifikat LP- 480 IDN sejak tahun 2010 dalam bidang pengujian kimia, khususnya uji banding parameter Besi. Salah satu parameter tingkat keberhasilan dalam mengikuti uji banding yang dengan mudah dapat dilihat dari nilai Z-Score. Hasil evaluasi uji banding dinyatakan baik apabila nilai angka Z-Score tersebut 
lebih kecil dari 2 (dua). Apabila terdapat nilai Z-Score yang mempunyai nilai lebih besar dari 3 (tiga) maka perlu dilakukan investigasi untuk mencari sumber kesalahan yang bisa terjadi pada tahap proses pengujian maupun pada tahap pengolahan dan analisa data.

\section{METODE PENELITIAN}

\section{Bahan uji banding antar laboratorium}

Bahan uji banding antar
laboratorium merupakan air demineralisasi yang diperkaya analit dengan kadar tertentu. Sebelum didistribusikan kepada laboratorium peserta, homogenitas dilakukan terhadap bahan uji banding antar laboratorium untuk menjamin bahwa bahan uji yang diterima setiap laboratorium peserta telah homogen. Adapun parameter kualitas air dalam program uji banding antar laboratorium hanya terbatas pada paremeter Besi dengan rentang konsentrasi 0.05-2.0 $\mathrm{mg} / \mathrm{l}$.

\section{Pengolahan data hasil uji}

Pengolahan data hasil uji banding antar laboratorium penguji berdasarkan ISO 13528:2005: Statistical Methods for use in proficiency Testing by Interlaboratory Comparisons, yaitu dengan metode teknik statistic Z-Score tanpa seleksi data terlebih dahulu. Tahapan awal untuk olah data adalah menghitung Algoritma A-Robust, perhitungan ini digunakan untuk menentukan nilai Konsensus. Nilai konsensus yang diperoleh digunakan untuk perhitungan Z-Score, perhitungan ini akan menghasilkan kesimpulan tentang kinerja masing-masing laboratorium. Nilai Z-Score dihitung berdasarkan persamaan 1 .

$Z-$ Score $=\frac{\mathrm{xi}-\mathrm{X}}{\mathrm{s}}$
Keterangan:

xi : nilai yang dilaporkan oleh peserta

$X$ : Nilai acuan/consensus

$\mathrm{S}$ : simpangan baku

Evaluasi nilai Z-score

dikelompokan menjadi 3 kategori:

a. Untuk $\mid Z$-score $\mid \leq 2.0$ dikategorikan memeaskan diberi lambang "OK"

b. Untuk $2.0<\mid$-score $\mid<3.0$ dikategorikan meragukan diberi lambang "\$"

c. Untuk 4-score $\quad \geq 3.0$ dikategorikan kurang memuaskan diberi lambang "\$\$"

\section{Hasil Penelitian dan Pembahasan}

Data kualitas lingkungan yang dihasilkan dari laboratorium, dapat dijadikan sebagai indikasi adanya pencemaran lingkungan sekaligus sebagai alat bukti dalam penegakan hukum lingkungan maupun dalam membuat perencanaan dan kebijakan dalam pengelolaan lingkungan hidup. Oleh karena itu, untuk mendapatkan validitas data pengujian parameter kualitas lingkungan yang dapat dipercaya dan dapat dipertanggungjawabkan sesuai dengan tujuan yang diharapkan, maka salah satu persyaratan yang harus dipenuhi oleh laboratorium adalah merencanakan serta menerapkan jaminan mutu hasil pengujian dengan mengikuti uji banding antar laboratorium. Keikutan uji banding ini merupakan upaya untuk mendiseminasikan nilai benar dan tertelusur (metrologicaly traceable value), dan akan digunakan nilai acuan (reference value) untuk menilai akurasi hasil uji laboratorium peserta.

Kegiatan uji banding antar laboratrorium diikuti 14 (empat belas) laboratorium yang telah terakreditasi dengan kode kode LUB-1, LUB--2, LUB4, LUB-6, LUB-7, LUB-8, LUB-,9, LUB- 
10, LUB-11, LUB-12, LUB-14, LUB-15, LUB-16, dan LUB-17. Dalam kegiatan uji banding antar laboratorium ini hanya terbatas pada parameter Besi yang merupakan lingkup akreditasi di Laboratorium Hidrologi dan Klimatologi Lingkungan Fakultas Geografi UGM dengan kode LUB-10, hasil uji banding disajikan pada tabel 1 .

Tabel 1. Hasil uji banding antar laboratorium penguji parameter Besi $(\mathrm{Fe})$

\begin{tabular}{|c|c|c|c|c|c|}
\hline \multirow[t]{2}{*}{ No } & \multirow{2}{*}{$\begin{array}{l}\text { Kode } \\
\text { Lab }\end{array}$} & \multicolumn{2}{|c|}{ Hasil analisis } & \multicolumn{2}{|c|}{ Z-Score } \\
\hline & & Data 1 & Data 2 & & \\
\hline 1 & LUB-1 & 1.41 & 1.41 & 4.16 & $\$ \$$ \\
\hline 2 & LUB-2 & 0.65 & 0.65 & -0.72 & OK \\
\hline 3 & LUB-4 & 0.78 & 0.78 & 0.12 & OK \\
\hline 4 & LUB-6 & 0.32 & 0.33 & -2.80 & $\$$ \\
\hline 5 & LUB-7 & 0.24 & 0.25 & -3.32 & $\$ \$$ \\
\hline 6 & LUB-8 & 0.807 & 0.824 & 0.35 & OK \\
\hline 7 & LUB-9 & 0.830 & 0.830 & 0.44 & OK \\
\hline 8 & LUB-10 & 0.900 & 0.94 & 1.02 & OK \\
\hline 9 & LUB-11 & 0.800 & 0.80 & 0,35 & OK \\
\hline 10 & LUB-12 & 0.570 & 0.57 & -1.23 & OK \\
\hline 11 & LUB-14 & 0.730 & 0.756 & 0.12 & OK \\
\hline 12 & LUB-15 & 1.100 & 1.100 & 2.17 & $\$$ \\
\hline 13 & LUB-16 & 0.7469 & 0.7461 & -0.10 & OK \\
\hline 14 & LUB-17 & 0.741 & 0.757 & -0.08 & OK \\
\hline
\end{tabular}

1. Sumber; BLH DIY,2018

Menurut gambar 1 terlihat hasil perhitungan nilai z-score data hasil pengukuran konsentrasi Besi menunjukkan nilai yang bervariasi, nilai Z-Score tertinggi 4.16 dan terendah 0.08 . Hasil evaluasi menunjukan bahwa bahwa terdapat dua laboratorium penguji yang berada dalam kategori kurang memuaskan, yaitu laboratorium dengan kode LUB-1 dengan nilai Z-Score 4.14 dan LUB-5 nilai z-score -3.32; dua laboratorium diragukan kode LUB 4 dengan nilai Z-Score 2.17 dan LUB-15 dengan nilai $Z$-score; sedangkan 10 (sepuluh) laboratorium penguji lainnya termasuk dalam kategori kompeten dan
Laboratorium Hidrologi dan Klimatologi Lingkungan Fakultas Geografi UGM merupakan salah satu laboratorium yang kompeten,sehingga kemampuan personil dalam melakukan pengujian tidak diragukan karena didukung oleh sumberdaya manusia yang berpengalaman dan kompeten.

Kompetensi laboratorium dapat dibuktikan dengan penerapan pengendalian mutu internal yang baik dan benar serta implementasi jaminan mutu diantaranya dengan mengikuti uji banding antar laboratorium yang penyelenggaraannya berdasarkan prinsip ISO/IEC 17043:2010 dan ISO 13528:2005 seperti halnya telah dilakukan oleh Laboratorium Hidrologi dan Klimatologi Lingkungan Fakultas Geografi yang merupakan jaminan mutu dari hasil pengujian. Jaminan mutu merupakan bagian dari manajemen mutu yang difokuskan pada pemberian keyakinan bahwa persyaratan mutu akan dipenuhi, hal ini merupakan komitmen yang harus diterapkan setiap laboratorium yang telah terakreditasi. Secara teknis jaminan mutu pengujian dapat diartikan sebagai keseluruhan kegiatan yang sistematik dan terencana yang diterapkan dalam pengujian, sehingga memberikan keyakinan yang memadai bahwa data yang dihasilkan memenuhi persyaratan mutu sehingga dapat diterima oleh pengguna. Pengendalian mutu adalah suatu tahapan dalam prosedur yang dilakukan untuk mengevaluasi suatu aspek teknis pengujian. Salah satu aspek teknis dalam pengujian adalah validasi metode pengujian. Validasi metode analisis adalah suatu proses penilaian terhadap metode analisis tertentu berdasarkan percobaan laboratorium untuk membuktikan bahwa metode tersebut memenuhi persyaratan untuk digunakan (Harmita, 2004: 117). 


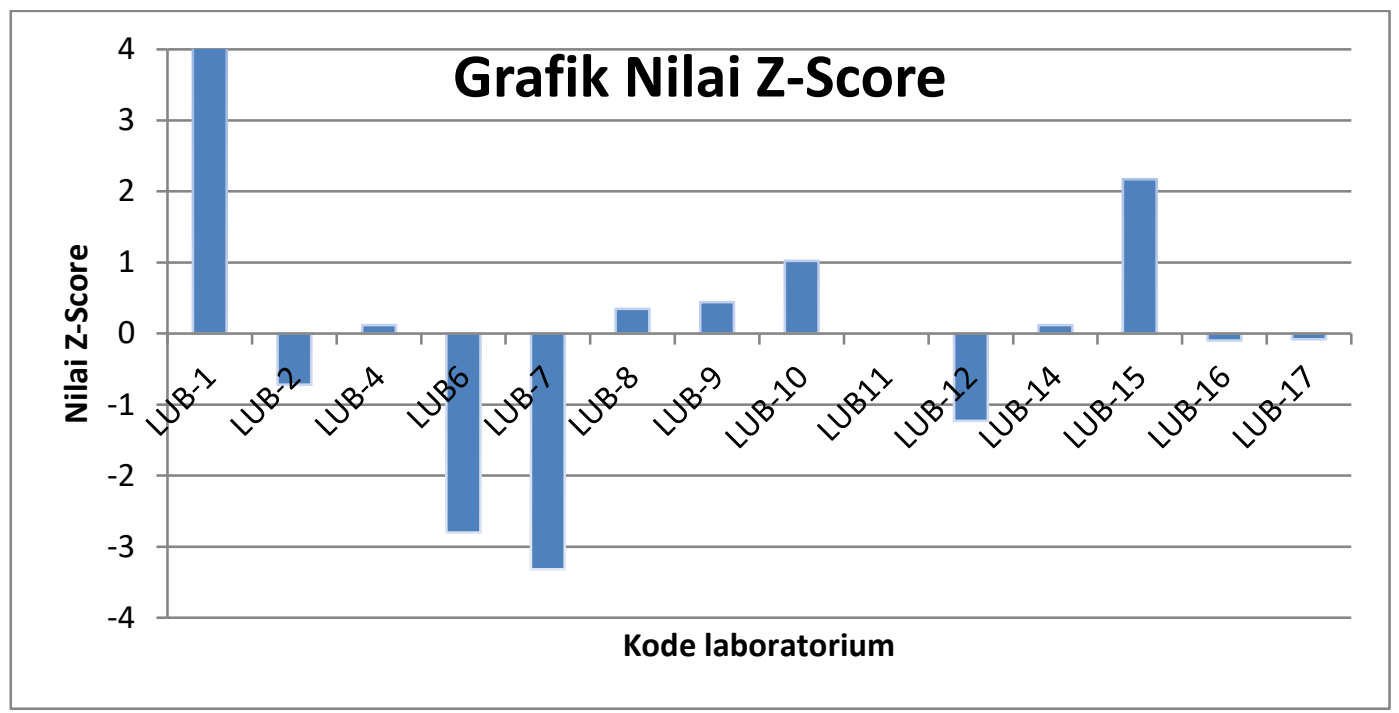

Gambar 1. Grafik nilai Z-score hasil uji banding parameter Besi

\section{KESIMPULAN}

Berdasarkan evaluasi uji banding antar labaoratorium yang diikuti sebanyak 14 (empat belas) laboratorium ternyata ada 2 laboratorium yang dikatagorikan tidak memuaskan, 2 laboratoium kategori diragukan dan 10 (sepuluh) laboratorium dinyatakan kompeten. Laboratorium Hidrologi dan Klimatologi Lingkungan Fakultas Geografi UGM merupakan laboratorium yang sudah terakreditasi oleh Komite Akreditasi Nasional (KAN) adalah salah satu laboratorium yang terlibat dalam uji banding dan dinyatakan laboratorium penguji yang kompeten, hal ini didukung oleh personil yang berpengalaman dan kompeten. Hasil dari uji banding antar laboratorium ini sebagai tolok ukur untuk evaluasi kinerja personil yang yang bekerja di laoratorium.

\section{DAFTAR PUSTAKA}

Anonim, 1997. Proficiency testing by interlaboratory comparisons part 1.

Anonim,2005. ISO 13528:2005: Statistical Methods for use in proficiency Testing by Interlaboratory Comparisons
Anonim, 2010. Conformity assessment - General requirements for proficiency testing

Badan Standarisasi Nasional,2017.SNI19-17025-2017Persyaratan Kompetens ilaboratorium Kalibrasi dan Penguji. Jakarta.

Styarini.D,2010. Uji Profisiensi. Pusat Penelitian Kimia. Kawasan PUSPIPTEK, Serpong Tangerang Selatan, Banten, Indonesia.

Harmita. (2004). "Petunjuk Pelaksanaan Metode dan Cara Perhitungannya". Majalah IImu Kefarmasian (Desember 2004).

Zaid,G., Dwi Larassati, Suherlan,2001. Analisa hasil uji banding antar laboratorium nasional tingkat Asia pasifik untuk termometer cairan dalam gelas. Jurnal Standardisasi Vol. 13 No. 3 Tahun 2011: 184191. 